\title{
Too Much Inequality or Too Little? Inequality and Stagnation in Ethiopian Agriculture
}

\author{
Stephen Devereux, Amdissa Teshome and \\ Rachel Sabates-Wheeler ${ }^{*}$
}

The agricultural sector remains our Achilles heel and source of vulnerability ... Nonetheless, we remain convinced that agricultural based development remains the only source of hope for Ethiopia. (Prime Minister Meles Zenawi 2000)

\section{Introduction}

A powerful strand of thinking about the causes of long-term agricultural stagnation in Ethiopia defines the problem in terms of inequality. Indeed, it is possible to interpret most Ethiopian agricultural policy initiatives of the past three decades in terms of divergent views on the extent and consequences of rural inequality. This article investigates the hypothesis that (too little rather than too much) inequality has contributed to agriculture's underperformance, and considers the implications for policy in terms of four alternative pathways for Ethiopian agriculture.

\section{Historical context}

Any Ethiopian over 40 years old has lived through three remarkably different political regimes: the feudal imperial era under Emperor Haile Selassie; the socialist military dictatorship of Colonel Mengistu's Derg; and the market-oriented, Westernaligned democracy of Prime Minister Meles Zenawi. Each regime has imposed an entirely different set of policies on smallholder agriculture, where over 80 per cent of the population makes its living, yet all three have presided over an agricultural sector that is stagnant and acutely vulnerable to recurrent drought and other livelihood shocks.
Following the "creeping coup" that overthrew Emperor Haile Selassie during the 1974 famine, the Derg implemented a radical agrarian transformation based on redistribution of land. Between 1976 and 1991, all rain-fed farmland in highland Ethiopia was confiscated and redistributed, after adjusting for soil quality and family size, among all rural households. This land reform was motivated not only by the Derg's Marxist egalitarian ideology, but by its conviction that feudal relations in agriculture had exposed millions of highland Ethiopians to intolerable levels of poverty and vulnerability. Redistribution therefore had both equity and efficiency objectives. It was implemented as a mechanism not just for breaking the power of the landlords, but also for eradicating historically entrenched inequalities in control over land, with the aim of achieving sustainable increases in agricultural productivity and rural incomes.

Was the Derg's economic analysis flawed? Hindsight suggests that the land reform was a political success but an economic failure. The Derg period is now remembered as a time of militarisation, war and repression, the worst African famine of the twentieth century, economic stagnation and failed development programmes villagisation, state farms, forced resettlement. Redistributing land may or may not have been a necessary step for enhancing rural livelihoods, but it was evidently not sufficient.

The Derg's land reforms did not extend to the right to buy and sell land, which constitutionally belongs jointly to the state and the people. Following

IDS Bulletin Vol 36 No 2 June 2005 @ Institute of Development Studies 
the overthrow of the Derg regime in 1991, the Ethiopian People's Revolutionary Democratic Front (EPRDF) government maintained the Derg's commitment to equality in land ownership. The EPRDF initiated its own redistribution programme in the early 1990s, to provide farmland for demobilised soldiers and to correct for the inevitable inequalities that develop over time as families grow at different rates, and young adults leave home and look for land to start their own farms. Throughout its rule, however, the EPRDF has maintained an implacable opposition to any suggestion that commercial principles should be introduced to land transactions in rural areas.

Prime Minister Meles argues that allowing land to become a tradable commodity would inevitably result in an 'urbanisation of rural poverty'. When the next major drought strikes, hungry families with nothing else to exchange for food will be forced to sell their land and, being displaced, will then migrate in enormous numbers to cities like Addis Ababa, where they will survive in squalor in squatter camps, with little prospect of securing formal employment. This is related to the "land as safety net" argument: even if tiny farms are inadequate for self-sufficiency, the family plot does provide some proportion of subsistence needs, and this safety net would be removed if land can be sold. Ideologically, the EPRDF shares the Derg's opposition to large landowners, and they believe that commercialising land will inexorably concentrate ownership in the hands of a minority. In his end-of-year report to Parliament in June 2004, Meles announced that the privatisation of land in Ethiopia would take place only 'over EPRDF's dead body'.

\section{Has equalisation in Ethiopia gone too far?}

Income inequality in Ethiopia is unusually low. The national consumption Gini coefficient in 1999 was just 0.28 , and was lower in rural than urban areas. The government interprets this both as a (negative) indicator of widespread poverty, and as a (positive) outcome of land redistribution.

The low level of inequality is consistent with the overall picture of Ethiopia as a very poor country, with a low per capita income. In addition, the egalitarian land holding system might have contributed to a more equal income distribution in rural Ethiopia. (FDRE 2002: 6)
Theory and evidence from a variety of contexts suggest that pro-poor redistribution of productive assets, especially land, can achieve significant increases in agricultural productivity. In contexts of imperfect markets, interventions that increase equality of access to assets should have a positive effect on the productivity of those who are worst affected by market failures. Eastwood et al. (2004: 2) hypothesise that very unequal land distribution (arising for historical and/or geographic reasons), retards agricultural development by concentrating much land, in countries still facing labour surpluses and capital constraints, into inappropriately large units with high capital/labour and land/labour ratios'.

However, under certain circumstances, redistribution may not result in productivity gains and could even lead to declines. Dercon (2003: 9) argues that 'if growth requires a certain threshold of local endowments to take off, then poorly endowed areas may well find it hard to escape poverty ... in densely populated areas such as Ethiopia or Bangladesh, redistribution or related policies such as tenure security are unlikely to achieve much more than a dent in poverty levels'. Carter et al. (2004) show that in the context of droughts in Ethiopia and hurricanes in Honduras, households that fall below a minimum "asset threshold" are unable to engineer successful asset accumulation. Scaled up to a community or region, these poverty traps have implications for asset distribution. Unlocking the growth potential of asset-poor areas may require policies that encourage consolidation of assets into larger holdings (through ownership, cooperatives, pooling or renting). Conversely, redistributing land and other assets equally in regions that have a very low resource base and are densely populated is likely to have adverse effects on productivity and poverty: some inequality may be beneficial for poverty reduction and efficiency.

So has equalisation gone too far in rural Ethiopia? The combination of land redistributions and prohibitions against land accumulation, declining access to natural resources and community-level assets (including grazing land and social capital), and asset sales for food in response to repeated shocks such as droughts, may have pushed hundreds of thousands of households in highland Ethiopia below the minimum threshold of key productive assets needed for a viable livelihood. 
According to this view, equalisation of assets in rural communities has contributed to agricultural stagnation, and is keeping the majority of Ethiopians trapped in poverty. Fear of future land redistributions - despite government assurances that none are planned - has inhibited investment in agriculture, while legal constraints against buying and selling land have prevented the consolidation of small, 'sub-subsistence' plots into larger, commercial farm enterprises.

A national survey in 2001 found that the average landholding in rural Ethiopia was approximately 1 ha per farming household, but just three-quarters of a hectare in Wollo and Tigray, where half of all households owned less than one-half of a hectare, and 10 per cent were landless (Berhanu Nega and Samuel Gebreselassie 2002: 35). However, this survey fails to distinguish between ownership of assets and access to assets. Rural communities have evolved a complex variety of oxen-sharing mechanisms, land-labour exchanges and land rental arrangements. These informal institutions serve to reallocate agricultural labour, draught power and farmland between households that have these key productive assets and those that lack them.

Despite being officially prohibited until recently, informal land rental markets have been active throughout rural Ethiopia for years. A survey in Tigray in 2000 found that 20 per cent of households were renting in land, while 39 per cent were renting out some ( 25 per cent) or all (14 per cent) of their land (Chiari 2002). Explanations given for renting out land (ranked) included: lack of oxen for ploughing, lack of male labour, and lack of seeds. Conversely, in-renters were mainly farmers with above average endowments of productive assets draught oxen, family labour and financial capital which allows them to both intensify and "extensify" their production. Wealthier households enjoyed higher crop yields and earned more income from crop sales, fodder sales and renting out oxen. So renting in land opens new pathways to further accumulation for better-off farmers (and leaves poorer households cultivating less land than they own), but it also provides an entrée into farming for newly formed landless households. Having independent control over land also enhances women's economic independence and gives them access to new sources of income and food: 57 per cent of out-renters in the Tigray survey were female-headed households with no access to male labour (Chiari 2002).

\section{Pathways for Ethiopian agriculture}

Ethiopian policy debates are vigorous and passionate, and several current "hot topics" - the Poverty Reduction Strategy, Productive Safety Nets Programme and Voluntary Resettlement Programme, among others - impact directly on agricultural livelihoods. Although these debates are often limited to a narrow, predetermined agenda or are invalidated by unrealistic assumptions about agricultural growth prospects, on one point most stakeholders and observers agree: there are no obvious remedies for the crisis in Ethiopian agriculture. This section discusses four broad pathways that a future agricultural strategy might take: intensification, diversification, commercialisation and "depopulation".

\subsection{Intensification of smallholder agriculture}

Following the conventional 'input-output' model of agriculture, this school of thought argues for enhancing smallholders' access to inputs such as improved seeds, fertilisers and draught power. This thinking underpins the Government of Ethiopia's extension programme, and projects such as Sasakawa Global 2000, which channels fertiliser and seeds to farmers on a revolving credit basis and has had some success in raising crop yields in some places at some times. Unfortunately, such schemes are prone to collapse (or require heavy subsidy) whenever a bad harvest undermines farmers' ability to repay their loans.

In any event, it is not low soil productivity per se that is the problem, but binding asset constraints and variability of yields. Cereal production in the highlands averages around 2 tons/ha if the rains are favourable, but since chronically food insecure households cultivate less than one-half of a hectare, they cannot produce enough food for self-sufficiency even in a good year. Given the certainty of erratic weather and failed harvests every few years, these smallholders are trapped in a low productivity trap, with plots that are too small to generate livelihoods from agriculture alone, and recurrent pressures to convert their dwindling assets into food. They are focused on surviving and managing shocks from one season to the next, and have no prospect of escaping poverty through agricultural intensification. 


\subsection{Livelihood diversification}

A key insight of the diversification literature is that factor productivity within agriculture (in terms of output/ha) matters much less than the proportion of livelihood derived from agriculture. Given the inability of most Ethiopian smallholders to make a living from agriculture, because of resource constraints and recurrent shocks, increasing policy attention has turned to supporting alternative livelihood activities. The government's strategy of 'Agriculture Development-Led Industrialisation' (ADLI) recognises the reciprocal linkages between agriculture and other sectors, but has had little discernible impact to date. Recently, the government has promoted "livelihoods packages" that aim to support secondary sources of income (such as beekeeping) by smallholder households, as a way of supplementing and diversifying household incomes against drought and other production shocks.

Another approach to supporting livelihood diversification within the rural economy is to promote the growth of small towns. Survey evidence from Wollo and Tigray provides strong confirmation of the benefits to rural households of being located within walking distance of urban centres. Towns provide access to employment, commodity markets (for food, agricultural inputs, and outputs such as crops and livestock products), and basic services (health and education). In Wollo, the government's decentralisation programme and the proclamation of towns as district or zonal capitals created local centres of economic growth that had beneficial effects throughout the surrounding villages (Devereux et al. 2003). In Tigray, significant differences in household incomes and agricultural production were recorded between villages located near and far from towns and markets. Income per unit of land was 62 per cent higher in a village near a town than in one with similar land endowments and distribution some $20 \mathrm{~km}$ away. A major determinant of this difference was the application of fertiliser, which was higher among farmers near town because of their preferential access to input credit and agricultural extension services (Chiari 2002).

\subsection{Commercialisation of agriculture}

Directly contradicting the prevailing preference for egalitarianism among Ethiopian policy-makers is the view that some degree of inequality may be necessary for achieving economic growth and poverty reduction. Within limits, therefore, inequality should be tolerated and allowed to rise from its present low levels. This argument acknowledges that policies of "equalisation" of assets have succeeded in reducing inequity in rural Ethiopia, but at the cost of eliminating entrepreneurial spirit and opportunities. 'Getting agriculture moving' requires giving incentives to individuals who invest in farming and develop businesses, not constraining their efforts. Generating income will create employment and income multipliers, increasing the tax base to finance government investment in jobs and services, including a more effective provision of social protection for the vulnerable. At the community level, this argument applies equally to informal providers of social protection. Evidence from Wollo suggests that a collapse in better-off groups within communities since the early 1990s has contributed to rising vulnerability and agricultural underperformance, since wealthier "patrons" are vital providers of access to resources such as oxen for ploughing, and of assistance in difficult years, to poorer community members (Devereux et al. 2003).

One obvious implication of this thinking is that entrepreneurial individuals should be allowed to accumulate land, which in turn would suggest privatising land rights and introducing market principles to land transactions. This would result in the consolidation of tiny family plots into large commercial farms, which might (or might not) be more efficient and productive, but would also displace those who sold up. Critics assert that this is arguing for a return to feudalism, or at least will lead to a re-stratification of rural communities into landowners and landless labourers. Others argue that this approach contradicts evidence for an "inverse relationship" between farm size and productivity: assuming this relationship holds, commercialisation will not raise productivity, and might reduce it. Two final critiques of this model are that it removes the safety net that access to land currently provides for rural households, and that it comes close to advocating a "trickle-down" approach to development, which is unlikely to generate pro-poor growth and sustainable poverty reduction.

For these and other reasons, the Ethiopian government is unlikely to favour commercialisation pathways - though alternatives such as new types 
of farmer organisations are yet to be explored. The government's preference for a pro-poor pattern of economic growth is explicit in its current poverty reduction programme.

The evidence suggests that there has been a positive correlation between economic growth and income inequality in Ethiopia. It is important to ensure, therefore, that more rapid economic growth does not lead to substantially higher levels of inequality. In other words, a pro-poor growth strategy is essential for rapid poverty reduction. (FDRE 2002: 26)

\subsection{Depopulation}

Another radical response to the crisis of smallholder agriculture might be called "depopulation". During the 1984/85 famine, and again in the ongoing and equally controversial - Voluntary Resettlement Programme (VRP), the Ethiopian government identified land scarcity as the binding constraint on highland agriculture, and relocation of farmers to lowland areas as the solution.

Under the current level of agricultural technology and overall development, areas referred to as drought areas cannot feed and support the people currently residing on them ... Therefore, resetting some of these people in areas where sufficient land and rainfall are available is one of the basic means to ensure food security. (FDRE 2001: 63)

Under the current initiative, the government plans to resettle 2.2 million people in three years, thereby alleviating pressure in the land-stressed highlands and providing "access to improved land" (where this is available) to families who agree to move (FDRE 2003). Concerns have been raised that resettlement is a misguided strategy that has invariably been implemented badly in Ethiopia again, early reports suggest serious implementation failures with the VRP - and it is therefore unlikely to achieve its objective of improving food security among resettlers (Dessalegn Rahmato 2003; Pankhurst 2003).

In livestock-dominant areas, the government has similarly responded to recent signs of stress in the pastoral economy - famine and/or drought in three of the last five years - by arguing for sedentarisation of pastoralists along rivers or in small towns. The Government of Ethiopia's 'Pastoral Development Policy' advocates: 'Phased voluntary sedentarisation along the banks of the major rivers as the main direction of transforming pastoral societies into agro-pastoral system, from mobility to sedentary life, from rural to small pastoral towns and urbanisation' (FDRE 2002: 5). In the authors' view, "settlement" of pastoralists and "resettlement" of farmers both respond to an assumption of binding natural resource constraints by introducing measures that are inappropriate and come close to social engineering. When asked for their views, pastoralists seem less enthusiastic than their government about choosing a sedentary future.

The Government wants to settle us, to turn us into farmers. But we look at the problems of the farmers in the highlands and we ask why the Government hasn't solved their problems. Every years millions of tons of food aid goes to those farmers, who are supposed to be growing their own food. Does the Government want to turn us into beggars like them? (Pastoralist from Somali Region, quoted in Devereux 2004: 9)

\section{Conclusion}

Ethiopian agriculture is at a crossroads - as always. Which pathway to take? Invest in farming or help smallholders to diversify away from farming? Commercialise agriculture and turn millions of farmers into landless labourers, or physically relocate millions of farmers out of the highlands altogether? At best, each of these options offers a partial solution; at worst they contradict each other and fail to address the underlying constraints - agro-ecological, demographic, economic, infrastructural, institutional, political - that have brought agriculture in highland Ethiopia to its present state of "chronic crisis".

Taken together, a strategy that combines elements of the above might make some difference: agricultural intensification, plus investing in livelihood diversification to reduce dependence on rain-fed agriculture, plus promoting small towns as growth nodes in rural districts, plus some (genuinely voluntary and well implemented) facilitation of migration from highly stressed to higher potential areas. Agricultural commercialisation might also be economically sensible and socially acceptable in some areas. A crucial and often repeated point is that none of these interventions will succeed without 
a major programme of "investing in the basics", especially infrastructure and institutions. Most fundamentally, however, visionary thinking involving farmers and pastoralists as full and equal

\section{Note}

* This article draws from two background papers commissioned for the 2006 World Development Report on 'Inequality': Amdissa Teshome and Devereux (2004) and Sabates-Wheeler (2004). Funding support from DFID is acknowledged.

\section{References}

Amdissa Teshome and Devereux, S., 2004, 'Inequality and agriculture in Ethiopia: a case study', WDR Background Paper on Asset Inequality and Agricultural Productivity, Brighton: Institute of Development Studies

Berhanu Nega and Samuel Gebreselassie, 2002, Land Tenure and Agricultural Development in Ethiopia, Addis Ababa: Ethiopian Economic Association

Carter, M., Little, P., Tewodaj Mogues and Workneh Negatu, 2004, Shocks, Sensitivity and Resilience: Tracking the Economic Impacts of Environmental Disaster on Assets in Ethiopia and Honduras. University of Manchester: Institute for Development Policy and Management (IDPM) Chiari, G.P., 2002, 'Land tenure and livelihood security in Tigray, Ethiopia', DPhil dissertation, Institute of Development Studies, Brighton

Dercon, S., 2003, 'The Microeconomics of Poverty and Inequality: The Equity-Efficiency Trade-Off Revisited', Poverty, Inequality and Growth: Proceedings of the AFD-EUDN Conference, 2003, Paris: Agence Francaise de Developpement

Dessalegn Rahmato, 2003, 'Resettlement in Ethiopia: The tragedy of population relocation in the 1980s', FSS Discussion Paper No 11, Addis Ababa: Forum for Social Studies

Devereux, S., 2004, 'Food security issues in Ethiopia: comparisons and contrasts between lowland and highland areas', seminar paper, 16 February, Pastoralist Communication Initiative [PCI]/ UNOCHA, Addis Ababa participants - is needed about where Ethiopian agriculture is headed in the long run, and how to achieve the structural transformation required to get there.
Devereux, S., Sharp, K. and Yared Amare, 2003, 'Destitution in Wollo, Ethiopia', IDS Research Report 55, Brighton: Institute of Development Studies

Eastwood, R., Kirsten, J. and Lipton, M., 2004, 'Premature deagriculturalisation? Land inequality and rural dependency in Limpopo Province, South Africa', Journal of Development Studies

FDRE (Federal Democratic Republic of Ethiopia), 2003, The New Coalition for Food Security in Ethiopia, Vol II - Voluntary Resettlement Programme (Access to Improved Land), Addis Ababa: Government of Ethiopia

FDRE, 2002, Ethiopia: Sustainable Development and Poverty Reduction Program, Addis Ababa: Ministry of Finance and Economic Development

FDRE, 2002, Statement on Pastoralist Development Policy, Addis Ababa: Ministry of Federal Affairs FDRE, 2001, Rural Development Policies, Strategies and Instruments, Addis Ababa: Ministry of Information

Pankhurst, A., 2003, 'Longer term implications of resettlement in Ethiopia', paper presented at the Workshop on Settlement and Resettlement in Ethiopia, 28-30 January, ESSSWA/UN-EUE, Addis Ababa

Sabates-Wheeler, R., 2004, 'Asset inequality and agricultural growth: how are patterns of asset inequality established and reproduced?', WDR Background Paper on Asset Inequality and Agricultural Productivity, Brighton: Institute of Development Studies 